\title{
AN APPROACH FOR CALCULATING LAND VALUATION BY USING INSPIRE DATA MODELS
}

\author{
A.C. Aydinoglu ${ }^{a}, *$ R. Bovkir ${ }^{a}$ \\ ${ }^{a}$ Dept. of Geomatics Engineering, Gebze Technical University, 41400, Gebze, Kocaeli, Turkey - (aydinoglu, rbovkir) @ gtu.edu.tr
}

KEY WORDS: Geographic Data Infrastructures, INSPIRE, interoperability, land valuation, geographic data models

\begin{abstract}
:
Land valuation is a highly important concept for societies and governments have always emphasis on the process especially for taxation, expropriation, market capitalization and economic activity purposes. To success an interoperable and standardised land valuation, INSPIRE data models can be very practical and effective. If data used in land valuation process produced in compliance with INSPIRE specifications, a reliable and effective land valuation process can be performed. In this study, possibility of the performing land valuation process with using the INSPIRE data models was analysed and with the help of Geographic Information Systems (GIS) a case study in Pendik was implemented. For this purpose, firstly data analysis and gathering was performed. After, different data structures were transformed according to the INSPIRE data model requirements. For each data set necessary ETL (Extract-Transform-Load) tools were produced and all data transformed according to the target data requirements. With the availability and practicability of spatial analysis tools of GIS software, land valuation calculations were performed for study area.
\end{abstract}

\section{INTRODUCTION}

Standardised and interoperable data has significant importance in achieving successful land administration and applications. Geographic enablement and efficient information management can be ensured with the existence of definitive and reliable land administration systems (LAS) (UNECE, 1996; Williamson, 2005). In this point of view, data sets should be interoperable and shared through open services for making the data accessible and reusable in various land-related applications (Lakomaa et.al., 2013). Once different datasets are produced interoperable way, various land related applications can be performed easily and reliably (Aydinoglu and Bovkir, 2017). Thus, applications like land valuation, rural-urban transformation, expropriation, land consolidation, etc. can effectively be performed throughout the government agencies.

For the solution of the interoperability issues with the purpose of developing geographic data production and sharing standards, the concept of Geographic Data Infrastructures (GDI) has emerged (Budic et al., 2004). Governments and geographic data organizations developed their own GDI to specify their standards and manipulate their geographic data effectively throughout the different applications. Infrastructure for Spatial Information in Europe (INSPIRE) aims to make geographic information more accessible, practical and interoperable within the Europe.

Land valuation is a highly important concept for societies and governments have always emphasis on the process especially for taxation, expropriation, market capitalization and economic activity purposes (Yalpir, 2007). Because of the intensively performed urban transformation applications, real estate valuation has increased its importance within the sector in Turkey as such in many other countries. To success an interoperable and standardised land valuation, INSPIRE data models can be very practical and effective. If data used in land valuation process produced in compliance with INSPIRE specifications, a reliable and effective land valuation process can be performed.
In this study, possibility of the performing land valuation process with using the INSPIRE data models was analysed and with the help of Geographic Information Systems (GIS) a case study in Pendik was implemented. For this purpose, firstly data analysis and gathering was performed. After, different data structures were transformed according to the INSPIRE data model requirements. For each data set necessary ETL (ExtractTransform-Load) tools were produced and all data transformed according to the target data requirements. With the availability and practicability of spatial analysis tools of GIS software, land valuation calculations were performed for study area.

\section{METHODOLOGY}

\subsection{Determining Factors Effecting Land Value}

In real terms, it is difficult to determine the exact value of real estate because of the many different factors related to location and utilization that varies from person to person in terms of quality and quantity (Yomralioglu and Nisanci, 2004). According to the application needs or personal subjective expectations, different thematic factors may need to be examined.

The most general excepted factors that significantly affects the value of the real estate are determined according to the academic researches, nationally and internationally accepted standard documents (CMB, 2006; TDUB, 2011; IVSC, 2011, TKGM, 2011; RICS, 2014; TEGoVA, 2016; Yomralioglu 1993; Candas 2012). Determined and complied factors are grouped into four main categories according to their relations as Legal Factors, Locational Factors, Physical/Zoning Factors and SocioEconomic Factors.

\subsection{INSPIRE Data Analysis}

Determined factors were evaluated and examined with respect to the INSPIRE geographic data specifications for the purpose of analysing the possibility and effectivity of performing a land valuation process by using INSPIRE data models. For this

\footnotetext{
* Corresponding author
} 
purpose, matching tables were created and each criteria and corresponding data themes were analysed and listed.

After the evaluation, it was determined that data themes corresponding most of the factors are available within INSPIRE data models. Analysing the availability of these criteria shows the possibility to carry out land evaluation with standardised public data within the INSPIRE.

\subsection{Data Gathering and Transformation}

Pendik district of Istanbul province was chosen as the study area for the application and available data for the valuation process was gathered for study area. To overcome the interoperability challenges and provide accurate and defined geographic data sets to the users, ETL tools were used for enabling data transformation between source datasets and target data schemas.

In ETL process firstly schema matching step was performed. Related attributes of source and target schemas were matched. After schema matching, schema mapping and transformation steps were performed. Humbold Alignment Editor (HALE) was used for the transformation process and source data transformed according to the INSPIRE data models for study area.

\section{CASE STUDY}

The parameters affecting real estate value are complex and depending on various parameters. Therefore, with the help of statistical approaches better evaluations can be performed about the real estate (Yomralioglu and Nisanci, 2004). The basis of statistical evaluation is to create a mathematical model with numerical or proportional relations between real estate value and real estate related factors.

Because information can be the form of verbal expressions such as large, small and little in fuzzy logic, it is an effective method for processing oral variables, which is very important for valuation process (Nedeljkovic, 2006). That's why in this study for real estate evaluation process fuzzy logic is used with geographic analysis functions.

Fuzzy membership functions were defined and applied due to the characteristics for each determined thematic factor. In this way, each pixel in the raster data receives different pixel values ranging from 0 to 1 . Value estimation can be performed by integrating the values of each thematic group. For the integration, weighted overlay analysis was performed and overlay map was produced (Figure 1). Produced map demonstrates the value trends for the study area.

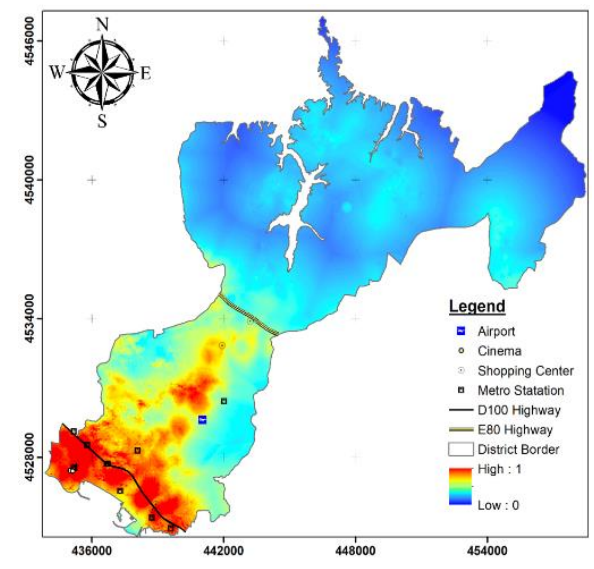

Figure 1. Weighted fuzzy overlay map

\section{DISCUSSION AND CONCLUSION}

Overlay operation of each fuzzy based factor groups gives a general evaluation approach for real estate related factors. Produced value trends from the analysis reflected close and logical tendency to the reality. It is seen that coastline and the area near the D100 highway have high values and the rural areas near to the Omerli Dam have low values (Figure 1). Also, near to the metro stations, Sabiha Gokcen Airport and attraction centers (shopping centers, cinema) have high values.

By using INSPIRE data models for land valuation process, reliable and effective land valuation process can be performed by using interoperable and public datasets. If required data can be obtained at the same standard, not only real estate evaluation application but also many land related applications can be performed easily.

\section{REFERENCES}

Aydinoglu, A.C. and Bovkir, R., 2017. Generic Land Registry and Cadastre Data Model Supporting Interoperability based on International Standards for Turkey. Land Use Policy, 68(2017), 59-71.

Candas, E., 2012. Taşınmaz Değerlemesi İçin Mevzuat Altyapısının Modellenmesi, Thesis (MSc). Istanbul Technical University.

CMB (Capital Markets Board of Turkey), 2006. Sermaye Piyasasında Uluslararası Değerleme Standartlarl Hakkında Tebliğ. Ankara: Capital Markets Board of Turkey.

International Valuation Standards Council (IVSC), 2011. International Valuation Standards. London: International Valuation Standards Council.

Lakomaa, E., Kallberg, J., 2013. Open Data as a Foundation for Innovation: The Enabling Effect of Free Public Sector Information for Entrepreneurs. IEEE Access, 1, pp. 558-563.

Nedeljkovic, I., 2006. Image Classification Based on Fuzzy Logic. Remote Sensing and Spatial Information Sciences, 34, 16.

Royal Institution of Chartered Surveyors (RICS), 2014. Professional Valuation Standards. London: Valuation Professional Group of the Royal Institution of Chartered Surveyors.

TDUB (Turkish Appraisers Association), 2011. TUGDES (Turkey Valuation Standards) Draft Study.

TEGoVA (The European Group of Valuers' Associations), 2016. European Valuation Standards. 8th Edition, Belgium: Gillis Printing.

TKGM, 2011. 4th Component of Land Registry and Cadastre Modernization Project (TKMP): Determination and registration of real estate value. Ankara: General Directorate of Land Registry and Cadastre.

UN/ECE (The United Nations Economic Commission for Europe), 1996. Land Administration Guidelines - With Special Reference to Countries in Transition. Geneva: United Nations/Economic Commission for Europe. 
Williamson, I., 2005. A Land Administration Vision. Expert Group Meeting Incorporating Sustainable Development Objectives into ICT Enabled LAS, 9-11 November Melbourne.

Yalpir S., 2007. Bulanık Mantik Metodolojisi ile Taşınmaz Değerleme Modelinin Geliştirilmesi ve Uygulanması: Konya Örneği, Doctorate Thesis. Selcuk University.

Yomralioglu, T., 1993. A Nominal Asset Value-Based Approach for Land Readjustment and Its Implementation Using Geographical Information Systems, Thesis (PhD). Newcastle University.

Yomralioglu, T. and Nisanci, R., 2004. Nominal Asset Land Valuation Technique by GIS. FIG Working Week 2004, 22-27 May Athens. 